\title{
THE STRATEGY OF PHYSIOLOGICAL AROUSAL OF ATHLETES IN SPORTS COMPETITION BASED ON DRUG INTERVENTION
}

\author{
A ESTRATÉGIA DA EXCITAÇÃO FISIOLÓGICA DE ATLETAS EM COMPETIÇÕES ESPORTIVAS COM BASE \\ EM INTERVENÇÃOMEDICAMENTOSA
}

DEPORTISTAS BASADOS EN INTERVENCIONES FARMACÉUTICAS, ESTRATEGIA FISIOLÓGICA DEDESPERTAR

\section{Jiao Chen ${ }^{1}$ (ID) \\ (Public Health) \\ Hongtao Li $(\mathbb{D})$ \\ (Sports Engineering)}

1. Hunan University of Techology, Zhuzhou 412008, Hunan, China. 2. Institute of Physical Education, Xiangnan University, Chenzhou 423000, Hunan, China.

\section{Correspondence:}

Chenzhou 423000, Hunan, China. df333481@21cn.com ac10344@21cn.com

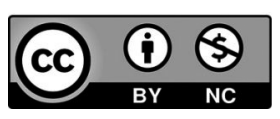

\begin{abstract}
Generally speaking, the physiological index of the human body is in a relatively stable state, which refers to the function of various organ systems with the characteristics of high-tide period, low-tide period and critical period. However, for competitive athletes, it is necessary to maintain physiological activation in both training and competition. In view of this, this study will analyze the physiological arousal degree of aspirin and acetaminophen in order to provide a reference for athletes to take analgesic drugs. In this study, the analytic hierarchy process (AHP), principal component analysis and factor analysis, were used to construct a scientific evaluation system of physiological arousal level, and the medication and non-medication status of 90 athletes were evaluated. The results showed that aspirin was better than acetaminophen in blood urea and serum creatine kinase, and the comprehensive score of some athletes was higher than 0.95. Aspirin is better in arousing athletes' physiology. The research results will provide scientific guidance for athletes to take antipyretic and analgesic drugs.
\end{abstract}

Keywords: Drug Therapy; Sports; Arousal; Aspirin; Paracetamol.

\section{RESUMO}

Em termos gerais, o índice fisiológico do corpo humano encontra-se num estado relativamente estável, que se refere à função de vários sistemas de órgãos no corpo humano, com as características do período de altas, período de baixas e perío do crítico. No entanto, para atletas competitivos, é necessário manter a ativação fisiológica em treinamento e competição. Em vista disso, este estudo irá analisar o grau fisiológico de excitação de aspirina e acetaminofeno, a fim de fornecer referência para os atletas a tomar medicamentos analgésicos. Neste estudo, 0 Analytic Hierarchy Process (AHP), análise de componentes principal e análise de fatores foram usados para construir um sistema de avaliação científica de nível de excitação fisiológica, e o estado de medicação e de não medicação de 90 atletas foram avaliados. Os resultados mostraram que a aspirina foi melhor do que o acetaminofeno na ureia sanguínea e na creatina quinase sérica, e o escore abrangente de alguns atletas foi maior do que 0.95. A aspirina é melhor no despertar da fisiologia dos atletas. Os resultados da pesquisa fornecerão orientação científica para os atletas tomarem medicamentos antipiréticos e analgésicos.

Descritores: Tratamento Farmacológico; Esporte; Nível de Alerta; Aspirina; Paracetamol.

\section{RESUMEN}

En términos generales, el índice fisiológico del cuerpo humano se encuentra en un estado relativamente estable, que se refiere a la función de varios sistemas de órganos en el cuerpo humano, con las características del período de altas, perío do de bajas y período crítico. Mientras tanto, para atletas competitivos, es necesario mantener la activación fisiológica en entrenamiento y competición. En vista de eso, este estudio analizará el grado fisiológico de excitación de aspirina y acetaminofeno, a fin de proveer referencia para los atletas para tomar medicamentos analgésicos. En este estudio, el Analytic Hierarchy Process (AHP), análisis de componentes principal y análisis de fatores fueron usados para construir un sistema de evaluación científica de nivel de excitación fisiológica, y el estado de medicación y de no medicación de 90 atletas fueron evaluados. Los resultados mostraron que la aspirina fue mejor que el acetaminofeno en la urea sanguínea y en la creatina quinasa sérica, y el escore abarcador de algunos atletas fue mayor de 0.95. La aspirina es mejor en el despertar de la fisiología de los atletas. Los resultados de la investigación proveerán orientación científica para que los atletas tomen medicamentos antipiréticos y analgésicos.

Descriptores: Tratamiento Farmacológico; Deporte; Nivel de Alerta; Aspirina; Paracetamol. 


\section{INTRODUCTION}

In competitive sports, athletes need to maintain a stable physiological state, with excellent physical fitness, in order to maintain enthusiasm for sports events, and play the best level in the competition. To improve the level of physiological arousal of athletes is an important means to improve their performance and ability to play on the spot. ${ }^{1}$ The physiological arousal of athletes is a neutral concept, which can accelerate the athlete's heart rate and metabolism speed, accompanied by shortness of breath, increased blood pressure, hormone secretion, etc. Moderate physiological arousal is the best level to promote the improvement of body function. Excessive physiological arousal may lead to impulsive and extreme behaviors of the awakened. Long term physiological arousal will lead to imbalance of various hormone levels in the body, which will affect long-term health. Stimulants and drugs can cause a high degree of physiological arousal. But the national regulations allow athletes to take analgesic, anti-inflammatory, breathing and other drugs can reduce the physical burden of athletes, and ensure that athletes play a better level of competition. ${ }^{2}$ Take antipyretic and analgesic aspirin and acetaminophen as examples, both belong to non steroidal anti-inflammatory drugs, and can play a physiological arousal state.,4 However, the level of physiological arousal of athletes is different between the two. This study constructed a scientific physiological arousal evaluation system and analyzed the physiological arousal level of two kinds of analgesic drugs, aiming to provide certain reference for athletes to take medicine.

In this study, firstly, the pharmacological mechanism of antipyretic, analgesic and anti-inflammatory effects of aspirin and paracetamol were elaborated. In the construction of physiological arousal level index system, the study first proposed a multi-level index system based on analytic hierarchy process (AHP), then reduced the dimension by principal component analysis, reduced the number of indicators on the basis of retaining the original index information, and finally used factor analysis method to re-examine the cross impact of secondary indicators on primary indicators, so as to construct a more scientific and reasonable simplification Objective system. Based on the actual investigation and expert opinion, the effect of drug intervention was evaluated by the index evaluation system.

This study innovatively combines the analytic hierarchy process (AHP), principal component analysis (PCA) and factor analysis (FA), abandoning the traditional index evaluation method of cumbersome calculation and repeated content. According to the internal relationship between data, the dimensions of multiple indicators constructed by AHP are reduced, and a more scientific evaluation system is constructed. The evaluation system can reflect the physiological arousal degree of different antipyretic and analgesic drugs on athletes through as few indicators as possible, which conforms to the characteristics of competitive athletes with high exercise intensity and less time, and is more suitable for the evaluation of athletes' physiological arousal level.

\section{RELATED WORKS}

Athletes' physical and mental health has an important impact on muscle regeneration, immune constitution and sports effect. At present, many scholars are committed to improving the level of athletes' physical and mental health, aiming to improve their sports physique and performance. Popova TV and other scholars conducted EEG tests on athletes aged 18 to 23 and unhealthy subjects, and found that athletes' endurance parameters were higher in dynamic performance and static tension than those in unsuitable subjects, and their fatigue ability was lower, which was consistent with the bioelectrical changes recorded in EEG. ${ }^{5}$ Steding ehrenborg K and other scholars conducted MRI examination on the hearts of athletes and healthy people, and found that the heart rate of athletes was $70 \pm 1 \%$, which was lower than that of normal heart rate, and the expenditure of cardiac blood kinetic energy of heart beat was higher. ${ }^{6}$ Oliveira GL D's team analyzed the incidence of eating disorder precursor syndrome and dissatisfaction with body image of 101 athletes in different sports events, and estimated body density and fat percentage using Siri equation. The results showed that athletes who participated in recommended weight control exercise were dissatisfied with their body image and risk factors of eating disorders even if their age, group and gender standards were healthy. In order to provide the left ventricular parameter index of young athletes in the growth process, mascherini G's team carried out accurate body composition analysis and echocardiography examination on 200 age-old athletes. It was found that the difference of heart adaptability between men and women began at puberty, and competitive sports played a certain role in promoting cardiac adaptability. ${ }^{8}$

Based on the above studies, scholars mostly study the influencing factors of athletes' physique from the aspects of athletes' nutrition intake, body unit, sleep condition, psychology and so on. There is little research on the stimulating effect of drug intervention on Athletes' physical function. In view of this, this study through the principal component analysis method to determine the marker factors of competitive athletes'labor-saving arousal, through the comparison of aspirin and acetaminophen two antipyretic analgesic drugs on Athletes' physiological arousal effect, put forward suggestions on Athletes' medication, and guide athletes to use drugs scientifically.

\section{CONSTRUCTION OF PHYSIOLOGICAL AROUSAL INDEX SYSTEM OF ATHLETES BASED ON ANALYTIC HIERARCHY PROCESS}

\section{Physiological arousal index system based on Analytic Hie- rarchy Process}

The analytic hierarchy process (AHP) is a decision-making method which decomposes the problems and related factors into objectives, criteria and other levels, and then carries out qualitative and quantitative analysis. This method is more suitable for the target system with hierarchical and staggered evaluation index, and the target value is not easy to describe quantitatively. The steps of using analytic hierarchy process to carry out target analysis are as follows: 1) to construct the hierarchical structure model; 2) to construct the judgment matrix; 3) to carry out the hierarchical single ranking and consistency test for the evaluation indexes; 4) to carry out the general arrangement and consistency test of the hierarchy.

The hierarchical structure model divides the decision-making objectives into the highest level, the middle level and the lowest level according to the relationship between the decision-making objects and certain criteria. The decision-making level is the problem to be solved. The middle level is the factors or decision-making criteria to be considered, while the lowest level refers to the alternatives in decision-making. By consulting a large number of literature and expert opinions, this study focuses on the top level structure of athletes' physiological arousal, which includes three aspects: Athletes'function evaluation, training monitoring performance and subjective experience. The level of athletes' physiological function can directly reflect the physical function status of sports mobilization.

Figure 1 is the evaluation index system of athletes' physiological arousal. The first level indexes were functional evaluation, training monitoring performance and nutritional recovery. The physiological function level of athletes can directly reflect the physical function of athletes. The evaluation methods mainly include blood index, urine index, etc., including pulse, blood pressure, body weight, hemoglobin, blood urea, serum creatine kinase, blood testosterone, etc. The evaluation of training 
monitoring performance is the score of athletes' state during training after drug intervention, mainly including muscle strength, mental state, endurance, etc. Subjective experience is the evaluation of athletes' physical function improvement after receiving drug intervention, including the degree of pain and fatigue.

Figure 2 shows the weight values of secondary indicators of this study based on expert opinions and previous research results. The weight values of the second level indicators under each level I index add up to 1.0 , the weight of the first level index "function evaluation" is 0.52 , the weight of training performance is 0.21 , the weight of self-evaluation is 0.27 , and the weight value of the three first level indicators is also 1.0. Hemoglobin endows red blood cells with the ability to transport oxygen, which is a common index to evaluate athletes' physical function. Blood urea is the evaluation index of protein metabolism in human body, which can reflect the exercise load of athletes. Serum creatine kinase (CK) is related to the important metabolic enzyme that can rapidly produce ATP (5'-adenylate phosphate) and recover ATP after exercise. The content of serum creatine kinase is closely related to the energy conversion of athletes during sports training. Therefore, the weight of the above three substances in the first level index "function evaluation" is relatively large.

\section{Effect of drug intervention on physiological arousal of sports athletes}

In this study, 90 male basketball players were investigated by questionnaire and expert interview. All the 90 athletes had two years or more sports experience, and did not take antipyretic and analgesic drugs in

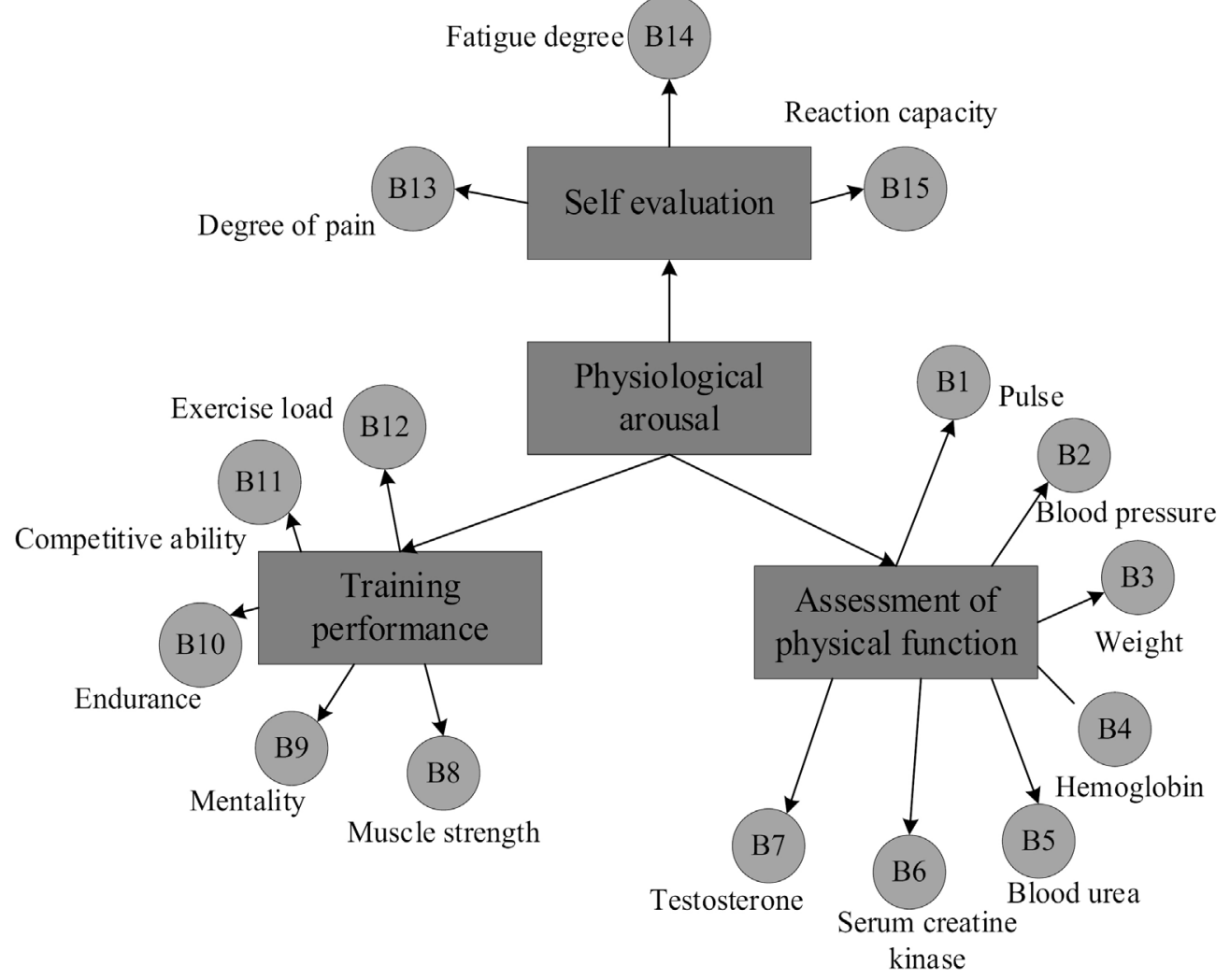

Figure 1. Evaluation index of athletes' physiological arousal.

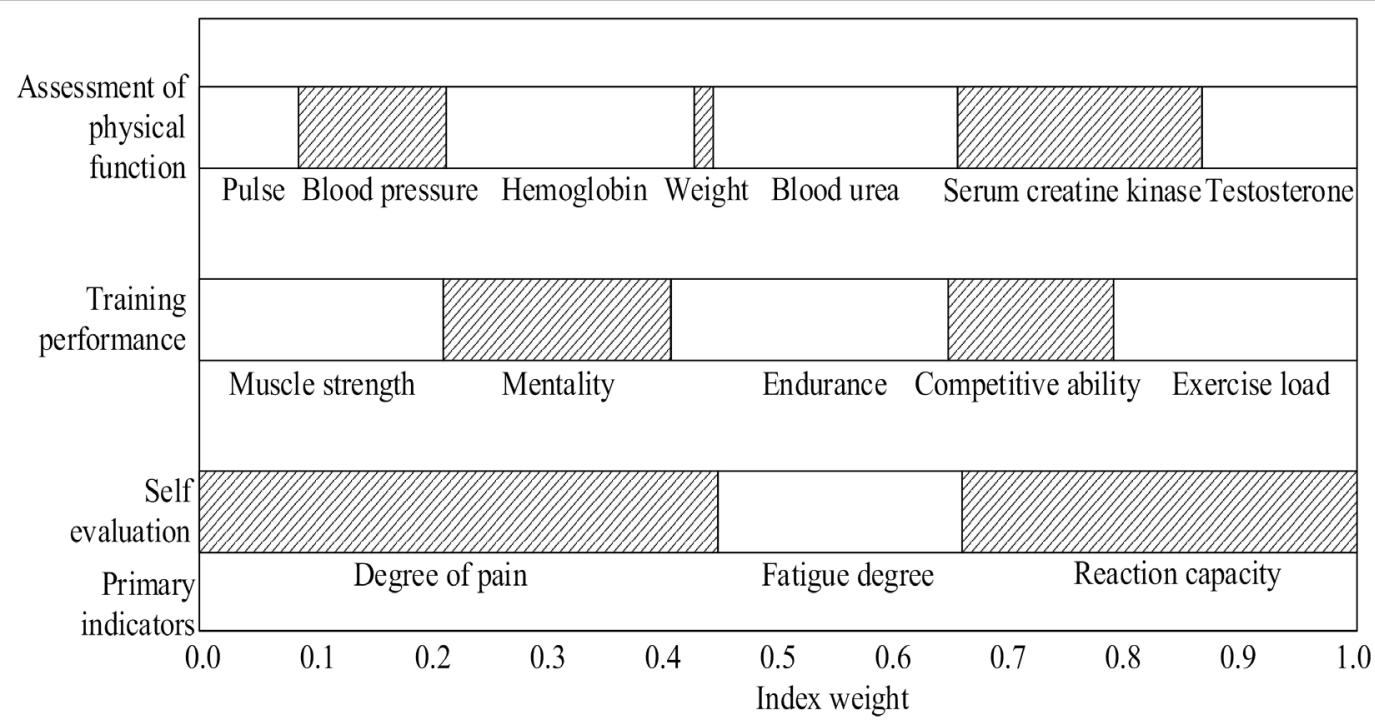

Figure 2. Evaluation weight of physiological arousal index. 
three months. The 90 athletes who participated in the study focused on the training of the same intensity in three weeks. They took aspirin, acetaminophen and did not take any antipyretic and analgesic drugs respectively. They were group A, group B and control group, 30 athletes in each group. The contents of pulse, blood urea and serum creatine kinase were measured twice a day. The coach and the athletes themselves scored their recent performance every two days.

In this study, principal component analysis (PCA) and factor analysis (FA) were used to reduce the 15 indexes that affect athletes' physiological arousal to 7. The consistency of the seven indicators was tested to judge the scientificity and rationality of the indicators.

Figure 3 shows the consistency test results of seven selected indicators in the study. The eigenvalues of the constructed matrix are 2.0-3.0. The consistency index values of B5, B6 and B13 are all 0, and the consistency index values of seven indicators are all less than 0.1 . Therefore, the physiological arousal level evaluation index selected in this study is reasonable in theory.

Figure 4 is the curve chart of physiological arousal level of athletes in groups a, B and C after three weeks of observation and data processing. The three curves are all in the shape of partial normal distribution. Taking antipyretic and analgesic drugs has different degrees of physiological arousal effect on athletes, but aspirin has more obvious physiological arousal effect on athletes. A small number of athletes who did not take

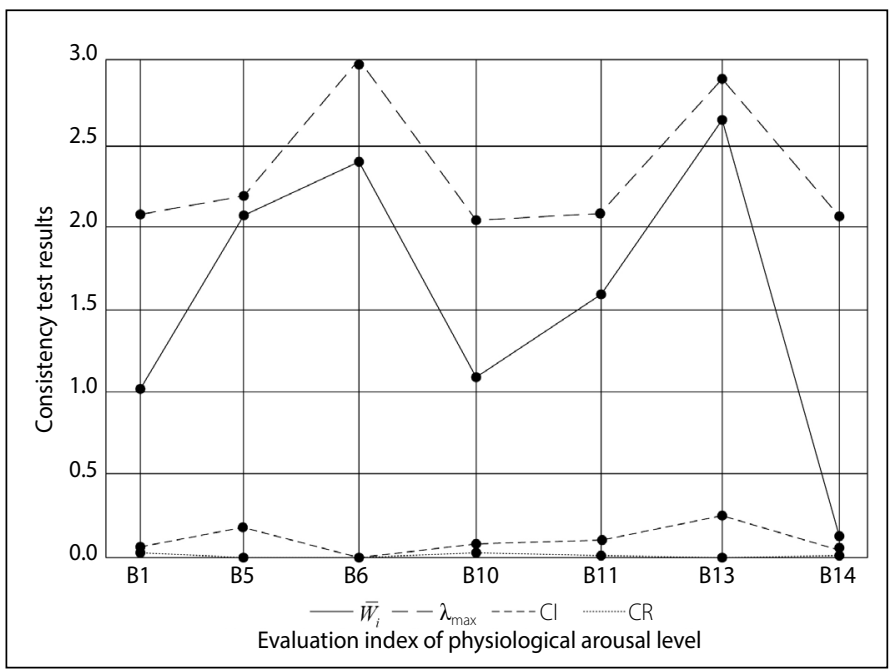

Figure 3. Consistency test results of physiological arousal level indicators. analgesic drugs showed mild physiological arousal phenomenon, which may be related to their own physical and psychological effects, but does not affect the judgment and analysis of the study.

The scores of the athletes taking aspirin and acetaminophen drugs in the seven indicators are shown in Figure 5, which shows the average value after removing the extreme values. The scores of aspirin on B1, B5, B6, B13 and B14 were higher than those of acetaminophen. The scores of B11 (competitive ability) of the two drugs were the same, while acetaminophen was better than aspirin in improving athletes' Sports endurance. Generally speaking, aspirin is more suitable for basketball players. However, acetaminophen can be considered for some sports that need long-term endurance, such as long-distance running.

\section{CONCLUSION}

The high-intensity competitiveness of competitive athletes requires that their body and spirit keep a high degree of tension and activation. However, due to the difference of personal constitution and professional years, and the athletes have more or less internal injuries. Therefore, it is very important to find the drugs that can stimulate and wake up the athletes' physiology. In this study, aspirin and acetaminophen on Athletes' physiological arousal level, first of all, using AHP, PCA, FA analysis method to construct a low-dimensional physiological arousal level evaluation system, and seven indicators for consistency test, the results show that

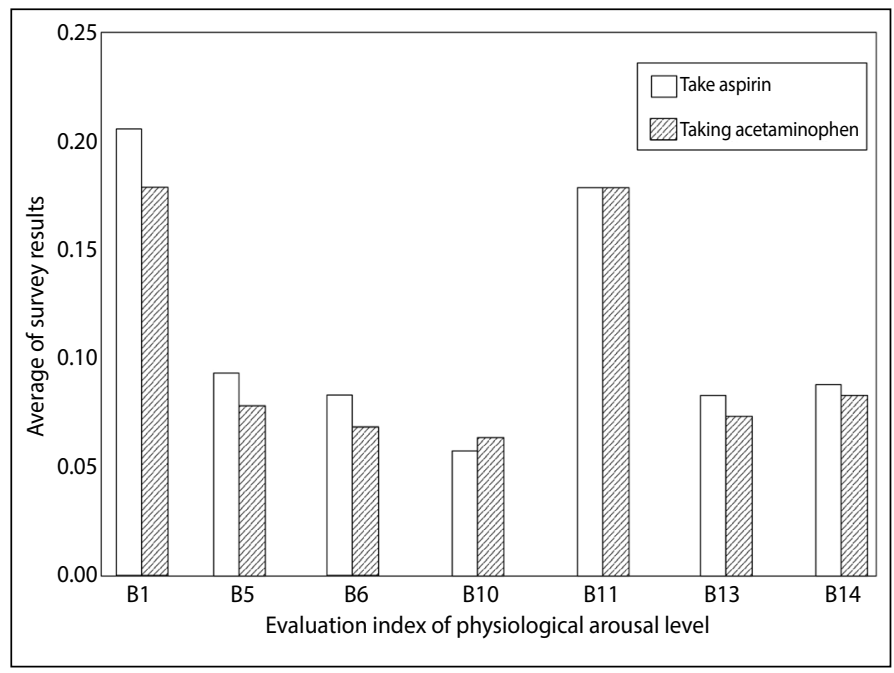

Figure 5. Score of each index of taking different analgesic drugs.

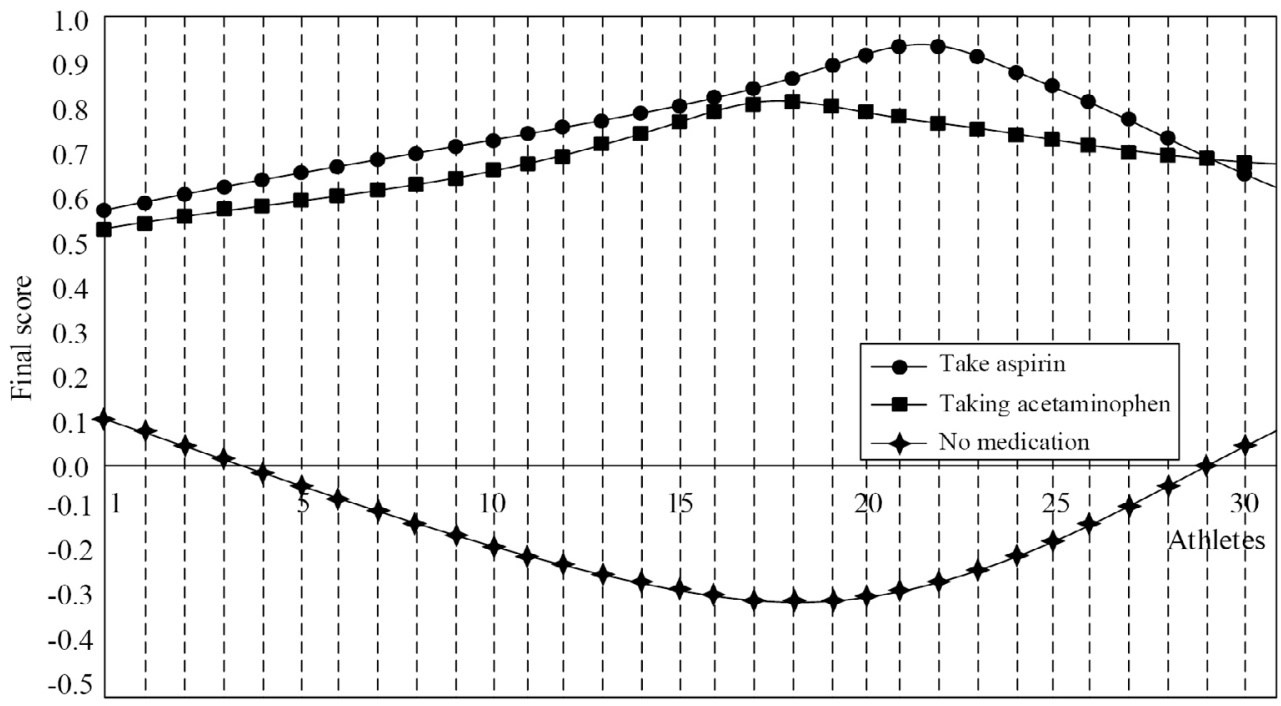

Figure 4. Athletes' final score of arousal level of physiological stimulation of two drugs. 
the consistency index values are less than 0.1 , which is scientific. The comprehensive effect of aspirin was better than that of paracetamol. The research methods and results will have a certain reference value for the theory and practice of subsequent athletes' physiological arousal. However, the index system constructed by the research is aimed at basketball players, and further analysis on the index system and drug effect of other players is needed.

All authors declare no potential conflict of interest related to this article

AUTHORS' CONTRIBUTIONS: The author has completed the writing of the article or the critical review of its knowledge content. This paper can be used as the final draft of the manuscript. Every author has made an important contribution to this manuscript. Hongtao Li': writing and execution. Jiao Chen: data analysis.

\section{REFERENCES}

1. Siegel AJ, Noakes TD. Aspirin to Prevent Sudden Cardiac Death in Athletes with High Coronary Artery Calcium Scores. The American Journal of Medicine, 2019; 132(2):138-141.

2. Siegel AJ. Aspirin Use to Reduce the Risk of Sports-Related Cardiac Arrest in High-Risk Athletes. The American Journal of Medicine. 2019; 132(3):e527-e528.

3. Forsdyke D, Smith A, Jones M, et al. Infographic: Psychosocial factors associated with outcomes of sports injury rehabilitation in competitive athletes. British Journal of Sports Medicine. 2017; 51(7):561-561.

4. Popovskaya MN, Moiseev SA, Ivanov SM, et al. Different Types of Muscle Contraction Regulation in Athletes Adapted to Stereotypical and Situational Motor Activity. Human physiology. 2019; 45(2):188-195.
5. Popova TV, Koryukalov YI, Kourova OG. Endurance and fatigue caused by local muscular performance in skilled athletes. Human Physiology. 2015; 41(6):680-682.

6. Steding-Ehrenborg K, Arvidsson PM, Töger J, Rydberg M, Heiberg E, Carlsson M, et al. Determinants of kinetic energy of blood flow in the four-chambered heart in athletes and sedentary controls. American Journal of Physiology Heart \& Circulatory Physiology. 2016; 310(1):H113.

7. Oliveira GL, Oliveira TAP, Gonçalves PSP, Valentim-Silva JR, Fernandes PR, Fernandes Filho J. Body image and eating disorders in female athletes of different sports. Journal of Exercise Physiology Online, 2017, 20(2):45-54.

8. Mascherini G, Petri C, Galanti G. Relationship between Left Ventricle and Body Composition in Young Male and Female Athletes. Human Physiology. 2018; 44(4):424-435. 